\title{
LET DANTE BE SILENT: FINNEGANS WAKE AND THE MEDIEVAL THEORY OF POLYSEMY ${ }^{1}$
}

\author{
LUCIA BOLDRINI
}

The medieval theory of the four levels of meaning has often been quoted by critics as a relevant model for the study of the multilayered language of Finnegans Wake. Dante's versions of the theory in the Convivio and the "Letter to Can Grande della Scala" are particularly important in this context, insofar as Dante was the first modern European poet to claim for his own love poetry the same interpretative method traditionally used for the divine word. In this essay I discuss whether Dante's theory can be "applied" to the Wake, or whether it is in fact already inscribed within Joyce's text, made part of its self-referential interpretative system, and with what effects for the theory as well as for the text. I argue that Dante's medieval exegetical model is transformed in the Wake through precise references that constantly evoke and confound Dante's terms, thus showing its inadequacy for the modern polysemic work but also, at the same time, acknowledging its fundamental role in the elaboration of such modern radical polysemy.

$$
* * *
$$

In the XXV canto of the Inferno Dante describes how thieves are subjected to complex metamorphoses, and underscores his poetic invention by bidding his classical precursors Lucan and Ovid be silent, as the changes they described could not bear out the comparison with his own superior inventiveness:

1. This essay is a shorter, revised version of chapter 1 of my Joyce, Dante and the Poetics of Literary Relations: Language and Meaning in Finnegans Wake, Cambridge: Cambridge UP, 2001. 
Taccia Lucano omai là dov' e' tocca

del misero Sabello e di Nasidio,

e attenda a udir quel ch'or si scocca.

Taccia di Cadmo e d'Aretusa Ovidio,

ché se quello in serpente e quella in fonte

converte poetando, io no lo 'nvidio.... (Inf. XXV, 95-99) ${ }^{2}$

("Let Lucan now be silent, where he tells of the wretched Sabellus and of Nasidius, and let him wait to hear what is now being fired. Of Cadmus and Arethusa let Ovid be silent, for if he converts by his poetry the one into a serpent and the other into a fountain, I do not envy him....”)

Dante's boastful self-appraisal achieves a double result: the poet acknowledges two of his main sources of inspiration, and simultaneously marks his departure from the pagan models he is imitating. The principal issue is one of originality (understood both as temporal anteriority and as novel treatment of one's poetic material) and of competition with one's sources and models in order to surpass them. What is really at issue is the assertion of one's own rights to authorship, the victorious reversal of Harold Bloom's notion of anxiety-laden influence into an appropriation of the anterior poet, guided by an awareness of one's superiority. But those who live by literature die by literature, and Dante's success in his competition with his predecessor has transformed him into a model to be appropriated (thieved) and transformed (metamorphosed) for new ends by his own successors.

Among the received notions in Joycean criticism, one of the most widespread is the importance of Dante's theory of the four levels of meaning for all of Joyce's works, and especially for

2. All quotations from the Commedia are from Dante Alighieri, $L a$ Commedia secondo l'antica vulgata, ed. Giorgio Petrocchi, Società Dantesca Italiana, Milan: Mondadori, 1966-1968; the translations are mine. 
Finnegans Wake, the "polysemous"3 text par excellence, whose layered meanings call for an adequately pluralistic interpretative framework. The Wake encourages its readers to interpret everything in the book on several levels of meaning, from its complex structure down to the single word: "spell me how every word will be bound over to carry three score and ten toptypsical readings" (FW 20.14-15). Dante's theory is particularly important not only because it is one of the most complete and advanced enunciations of the medieval theory of polysemy, but also because he was the first author in European vernacular literature to vindicate the validity of the fourfold allegorical model (until then only applied to Scriptural texts) for his own works. Thus Dante's allegory has been invoked as a convenient exegetical model since the very early stages of the Wake's composition, for instance by Joyce's friends Louis Gillet and Samuel Beckett. ${ }^{4}$ Harry Levin was the first and, as far as I am aware, the only one who tried to apply the theory to the Wake in order to identify more precisely what in Joyce's text would correspond to each of the literal, allegorical, moral and anagogical senses described by Dante. Levin presented the fourfold Dantean model as an attempt to find a way into Joyce's hermetic book:

Joyce's books are ... neither short nor long, but hermetic. We have so little critical equipment for divining a complex piece

3. Dante Alighieri, "Epistle to Can Grande", in Dantis Alagherii Epistolae, ed. and trans. Paget Toynbee, Oxford: Clarendon Press, 1920, pp. 160-211, §7.

4. "The text has to be read like Dante's, according to several superimposed meanings. There is a literal meaning, an allegorical meaning, and perhaps several others - almost as many as the skins of an onion". Louis Gillet, Claybook for James Joyce, trans. Georges MarkowTotevy, London and New York: Abelard-Schuman, 1958, p. 58. Cf. also Samuel Beckett, "Dante... Bruno. Vico.. Joyce", in Samuel Beckett et. al., Our Exagmination Round His Factification for Incamination of Work in Progress, London: Faber, (1929) 1951, pp. 3-22. For a more recent evaluation of the Wake through Dante's theory, cfr. Mary T. Reynolds, Joyce and Dante: The Shaping Imagination, Princeton: Princeton UP, 1981, and my Joyce, Dante, and the Poetics of Literary Relations. 
of symbolism that we may be excused for borrowing the terminology of the Middle Ages. That "divine comic," Dante Alighieri, explained to Can Grande della Scala that his own work could be interpreted at four different levels, and it may throw some light on Finnegans Wake to consider Joyce's "monomyth" in those terms. Anagogically, it envisages nothing less than the development of civilization, according to Vico's conceptions. Allegorically, it celebrates the topography and the atmosphere of the city of Dublin and its environs. Literally, it records the misadventure - or rather the nightmares - of H. C. Earwicker, as he and his wife and three children lie in their beds above his pub, and broken slumber reiterates the events of the day before. Morally, it fuses all these symbols into a central theme, which is incidentally Milton's - the problem of evil, of original sin."

Levin's words betray a certain sense of bemusement and echo the tone of dismay with which the young Stephen expressed the difficulty of finding an adequate language to represent the modern condition. ${ }^{6}$ Stephen's tentative poetics is based on a belief in the transcendent value of the medieval terminology, a stance Joyce had overcome by the time he wrote Finnegans Wake in favour of a more fruitful understanding and use of medieval poetics within a thoroughly modern aesthetics. But Levin need not apologise for "borrowing" the "terminology of the Middle Ages": this is not a case of simple borrowing of a useful tool on the part of the befuddled reader, nor is it an attempt by Joyce to locate in a medieval theory as adequate a model as may be found for his project. On the contrary, I would argue that the method is consciously and intentionally employed to explore the nature of polysemy, and that several allusions both to the Convivio and to the "Epistle" are woven into the Wake as a clue to the relevance of this

5. Harry Levin, James Joyce: A Critical Introduction, London: Faber, (1941) 1960, pp. 133-134.

6. "But in his expressions of love he found himself compelled to use what he called the feudal terminology..." (SH 174). See Jed Deppman's discussion of this passage earlier in this volume. 
issue, as an acknowledgment of Dante's "priority", and as a means to "silencing" and displacing the earlier writer. The reader, then, is justified in turning not just to the "terminology" but also to the methodology of the Middle Ages in order to gain a better understanding of Joyce's treatment of literary sources and of how Joyce's book functions with regard to the distribution and creation of meaning. I will therefore reconsider this literary / interpretative relationship, using Harry Levin's reading as my starting point and going back to Dante's texts to see whether his theory can be taken as such a straightforward, uncontroversial tool, applicable to another text without any further specifications. The theory will then be tested again on the Wake to find out how far it can be followed as a hermeneutical model. Thus in trying to answer the first, basic question - is Dante's theory of the four levels of meaning helpful for reading Finnegans Wake? - we shall inevitably raise others: is this just a reading strategy, a piece of external "critical equipment" in Levin's words, that the critic applies to Joyce's book in order to find his or her way around an otherwise nearly illegible text, or is it, on the contrary, an instrument whose interpretative function is already inscribed in, rather than having to be applied to, the Wake? And, should this second hypothesis be proved tenable, how is the theory integrated into the Wake's self-referential interpretative system? What kind of (hermeneutical) relationship is established between the medieval exegetical model and the modern literary polysemic work?

It may be appropriate to recall that Dante's well known theory of polysemy appears in two versions, one expounded in the Convivio, the other in the "Epistle to Can Grande della Scala". ${ }^{7}$ In the Convivio (the earlier of the two, written towards the beginning

7. The authorship of the "Epistle" is in fact still debated. Let it suffice to say, at this point, that it does not really matter whether Dante really wrote it or not: the "Epistle" is associated to his name, even if controversially, and it is in any case one of the most advanced expositions of the medieval theory of allegory, which is our main concern here. I shall therefore generally use the name of the Florentine poet as convenient shorthand for the author of both the Convivio and the "Epistle" and refer to the doubtful attribution when relevant. 
of the 14th century), Dante distinguishes between four levels of the meaning of the literary text: literal or historical (the immediate surface of the text, what it narrates); allegorical (the hidden but truthful sense); moral or tropological (the lesson that the text teaches its readers); and anagogical or "sovrasenso", i.e. the "sense above" (concerning spiritual, or "eternal" things). ${ }^{8}$ In the "Epistle" the layers of meaning carry the same name, but an additional, preliminary two-tier partition is introduced, and the levels are divided first into literal and allegorical, then the latter is further divided into allegorical proper, tropological and anagogical, so as to make the literal and allegorical levels the basic and most prominent ones. It is with these two that I will be concerned in the rest of this essay.

In the Convivio Dante contrasts the "allegory of the poets" with the "allegory of the theologians". ${ }^{9}$ This has been interpreted to mean that poets can use words in their works to signify something else from what they ostensibly appear to be saying, whereas the theologians interpret not only the Scriptures, but also nature and events, as signifying something more than themselves. That is because God can also use facts and things to signify, whereas the poet can only use words; the implication is therefore that the poets' allegory is a way of constructing meanings, but it can only be in verbis, whereas the theologians' is in facto, and can only be a means of interpretation of God's scripts, whose texts (verbal - the Holy texts - and material - the world) both are and signify. As Charles Singleton has put it, the poets' allegory is represented by the formula "this for that" (words may signify a hidden truth while they express a patent fiction), whereas the allegory of the theologian can be expressed by the words "this and that" (the

8. Dante Alighieri, Il Convivio, ridotto a miglior lezione e commentato da G. Busnelli e G. Vandelli. Con introduzione di Michele Barbi, seconda edizione con appendice di aggiornamento a cura di Enzo Antonio Quaglio, Florence: Le Monnier, 1964, II.i, 2-8. Subsequent references will be incorporated in the text; all translations are mine.

9. The following is an inevitably simplified sketch of the issue. On this see also Sam Slote's essay in this volume. 
words of the Bible are both literally and allegorically true). ${ }^{10}$ Dante suppresses the distinction between the allegories of the poets and of the theologians in the "Epistle to Can Grande", where the literal level is also described as being always true, no longer just a "beautiful fiction". Now, thanks to a revision of the theory which may be due, to some extent, to a more careful reading of St. Thomas, figurative language is seen as pertaining to the level of the letter; poets use it in order to make the things expressed intelligible to human minds, but this does not impair its truthfulness (as is also true of metaphorical language in the Bible). In Aquinas' words:

Although spiritual things are set forth under the figures of corporeal things, yet those things which are intended by sensible figures to concern spiritual things do not pertain to the mystical [or allegorical] sense, but to the literal; because the literal sense is that which is first intended by the words, either speaking properly or figuratively. ${ }^{11}$

What are the implications of Dante's theory - in its two different versions - for a reading of the Wake? Let us take, first of all, the literal level. Levin's starting point is that the literal meaning consists in the characters' dreaming, or having nightmares, while sleeping in their beds, and in their re-living the day's events. However, we know that Joyce did not write a book about a dream, i.e., about a character dreaming of something; he wanted to write the dream itself ("[Joyce's] writing is not about something; it is that something itself" ${ }^{2}$ ), in "dream language", to plunge that is the reader directly into the dreamer's mind, regardless of the identity of the dreamer. ${ }^{13}$ If the letter of Dante's Divine Comedy is the

10. "Dante's Allegory", Speculum, 25 (1950), p. 80.

11. Expositio in librum B. Iob, cap. i, lect. 2, quoted in Minnis, Medieval Theory of Authorship: Scholastic Literary Attitudes in the Later Middle Ages, Aldershot: Wilwood House, 1988, p. 74.

12. Samuel Beckett, "Dante... Bruno. Vico.. Joyce", p. 14.

13. Cf. H. S. Weaver's letter to J. S. Atherton of 30th August 1954: "My view is that Mr. Joyce did not intend the book to be looked upon as the dream of any one character, but that he regarded the dream form with 
"status animarum post mortem" ("Epistle to Can Grande", §8), that of Finnegans Wake is the "status animarum", as it were, per somnium - i.e., already inside the dream, in the sleeper's mind, or the "semitary of Somnionia" ( $F W 594.08)$ where the sleeping lie dead to the world. The literal meaning can then perhaps only be the manifest content of the dream (the surface operations of the dreamwork), told in its peculiar language from which a multiplicity of other meanings can be created / recovered by the critic or analyst. Let us therefore start from this basic hypothesis: that the literal meaning of the Wake as a whole may be identified as the dreamt story of H. C. Earwicker, innkeeper, and his family (rather than H.C.E. dreaming it): his wife Anna Livia Plurabelle, their twin sons Shem and Shaun, and their daughter Issy. H.C.E.'s "misdemeanour" in Phoenix Park, his encounter with the cad, and so on to include all the episodes that happen to the "characters", or "charictures in the drame" ( $F W 302.31-32)$, can be regarded as the story narrated in the book, the literal or "historical" sense.

If the literal level of Levin's exegesis is reinterpreted, the description of the other senses must also be rephrased. Levin reads the allegorical meaning as the celebration of the "topography and the atmosphere of the city of Dublin and its environs" (p. 134). This may be generally correct but perhaps too reductive; while the topographical elements may be seen, at one level, as the allegorical ("other") meaning of H.C.E., they also constitute, at another level, the physical context for H.C.E.'s story, and they must therefore be seen as elements of the literal level "hiding", or "containing" other allegorical meanings.

As a first, general, and probably very naive attempt to read in an allegorical way the events narrated at the literal level, we may therefore say that the latter signify, allegorically, the vicissitudes of

its shiftings and changes and chances as a convenient device, allowing the freest scope to introduce any material he wished - and suited to a nightpiece". Dear Miss Weaver: Harriet Shaw Weaver 1876-1961, ed. Jane Lidderdale and Mary Nicholson, London: Faber, 1970, p. 428; the excerpt is also quoted in James Atherton, The Books at the Wake: A Study of Literary Allusions in James Joyce's Finnegans Wake, Carbondale and Edwardsville: Southern Illinois UP, 1974, p. 17. 
Everyman - H.C.E. as Here Comes Everybody and Haveth Childers Everywhere. This, incidentally, is one of the well-known ways in which polysemy is made possible in Finnegans Wake: the "character"'s presence is marked by the appearance of his or her initials (or siglum) - i.e., typographical characters; but the initials may stand for something else beginning with the same letters. Thus an identification of all things, no matter how heterogeneous, is brought about by the sharing of the same initials - that is, the sharing of an apparently outward, superficial, arbitrary, and literally literal, or "letter-al", character(istic). The story of the family is also the story of the city of Dublin, whose citizens and territory they represent: "Howth Castle and Environs" ( $F W$ 3.03), the river Liffey, Chapelizod, the two banks of the river. Other topographical identifications follow: for instance, H.C.E.'s/Finn MacCool's head as the Howth promontory, the rest of his body dormant beneath the territory of Dublin; Shem and Shaun as the left and right banks of the river but also the people that live on them, including the two washerwomen that wash the dirty linen of H.C.E.'s family in the river and chat from the opposite banks; and so on.

There is hardly anything new in the above for anyone who has just dabbled in Finnegans Wake, but we already begin to encounter some serious problems with this reading. "Howth Castle and Environs" is not simply the allegorical meaning of H.C.E.: it is, rather, the "literal" meaning, whose initial letters signify the presence of H.C.E. In this case, the "character" suggested by the initials H.C.E. would represent the allegorical meaning included in the topographical detail. Chapter I.8 ostensibly tells of the washerwomen on the Liffey, their gossiping and their metamorphosis: how can we say, then, that this is an allegorical reading of the literal Shem and Shaun's everlasting opposition, and not the literal surface that displaces Shem and Shaun to the allegory? In other words, we may have to choose between two possibilities: a) if the letters H.C.E. and A.L.P. signal the presence of - i.e. stand for the archetypal man and woman, it would seem that the letters are, appropriately, the literal level, while each actual embodiment of the "characters" should be displaced to the allegorical. Or else, b) perhaps each character, or place, or object, etc., exists at the literal level only when $\mathrm{s} / \mathrm{he} / \mathrm{it}$ is named, while the other characters, 
objects, concepts, etc., represented by the same letters but not named on this occasion are located on the allegorical ("other") level. In either case, the reader seems to be asked to separate the letters - typographical characters - from the "actual" "personified" characters, and different embodiments of the characters from each other; in the first option proposed, we would have to identify the letters with the literal level and the "embodiments" with the allegorical, while in the second, we may have to do just the reverse. We seem to be getting entangled in a double reversal where the literal becomes allegory and the allegory becomes literal - where each element moves fluidly between levels of signification. (That "character" may signal both, obviously compounds the problem.)

Let us therefore consider once more what we have called the literal level, the story of H.C.E. and his family. This story is not linear; it does not have any immediately apparent coherent development. It is made up of many different plots, sketches, scenes of dialogue, confrontations of "characters", short interludes. Only after several readings does this polymorphic surface reveal some form of coherence, which the reader is able to identify thanks to the return of "characters" (or character-like roles) and, especially, the return of types of relationship between "characters" (e.g. antagonism and conflict, desire, temptation...). Thus the different "stories" appear to be in fact different versions of the same basic one, with similar underlying sets of meaning. They are one by one - or, more often, many of them simultaneously brought to the surface and cast into the role of "literal meaning", then plunged back again into the depth, to surface again, at other moments and usually in snatches, through linguistic hints, suggestions, overtones, letters. The "literal level" appears in fact extremely complex, made up of several levels which cross and interfere with one another, not exactly like "skins of an onion", ${ }^{14}$ placed in orderly strata, but rather like several threads of different lengths and thickness woven together to form a multicoloured and irregular fabric. Another suitable image would be the intricate interlacings found in medieval manuscripts and their illuminated letters, such as most notably, the Book of Kells, discussed by

\section{Gillet, p. 58.}


Guillemette Bolens in an earlier essay in this collection.

But this leads to yet another problem for our reading: how do we distinguish a figurative use of language at the literal level from the allegorical level of meaning, as Dante suggests by following Saint Thomas? The linguistic indices that actually appear on the narrative surface make it difficult to distinguish what is allegorically signified and what is on the contrary a figurative use of language and could therefore be ascribed to the lettera. Given the enormous number of legendary, historical, mythological, anecdotal, Biblical and literary references, if we consider that allusions of this kind are to be taken as figurative uses of language, and therefore as pertaining to the literal level, it would seem that nothing is left for the allegorical level, unless we understand the allegory to consist in an abstraction, a pattern of "common denominators" (with regard to character-like roles, sequences of events and structural or thematic relationships) which underlie the basic structure of all episodes in the Wake and can therefore be defined as the universal characteristics of mankind and the historical development of civilization - which, incidentally, is what Levin ascribes to the anagogical level.

The question is indeed hard to disentangle, just as it is hard to disentangle the narrative threads and chains of allusions that can be found in the Wake. The logical conclusion would be that while the theory of the fourfold meaning could be a useful conceptual tool (but one which is external to the Wake), any rigorous distinction between the actual meanings is virtually impossible, and any attempt at a strict application of the model is bound to be unsuccessful, proving even more confusing than the text which it proposes to explain. We would indeed end up where Levin had started, accepting the theory of the fourfold meaning as an interpretative grid to map, tentatively, on to the Wake but not as a structure which the Wake appropriates and incorporates into its semiotic system (if only to show its limitations), as I would on the contrary like to argue. In other words, we would end with an alternative between a "Dante map" as would be sought by the kind of imitator Pound exemplifies, in the sense which Dasenbrock and Mines illustrate in their essay earlier in this volume, and the deeper understanding of the value and import of the medieval theory 
which, according to my reading as well as Dasenbrock and Mines' interpretation, Joyce possessed.

If my assumption is right and the Wake does offer the keys to its riddles $(F W$ 628.15), the solution must then be sought in Finnegans Wake itself, in its allusions to the theory as Dante expressed it in the Convivio and in the "Epistle to Can Grande della Scala", and in the way these references are treated and transformed. We shall see that Joyce himself deliberately confuses the terms of Dante's formulation of the theory, undermining his source-model and therefore showing it to be inadequate if applied too rigidly to the Wake. As in the case of Ovid and Lucan in canto $\mathrm{XXV}$ of the Inferno, the earlier example is insufficient and surpassed. This does not mean, however, that the model should be discarded: it is in fact only by understanding exactly where it fails and how it is transformed that the reader can discover something about the nature of modern polysemy and about the intertextual relationship that the Wake establishes with the sources from which it borrows and the transformation it works upon them.

The majority of the references to the theory of the four levels of meaning, both from the Convivio and the "Epistle to Can Grande", appear in I.5, the chapter of the Wake most extensively devoted to interpretation / to the interpretation of the "Letter". The text draws upon the medieval theory of Dante, who speaks in a letter (his "Epistle") of the "letter" ("literal meaning"); at the same time, his terms are revised and shown to be insufficiently developed. The "letter" or "mamafesta" is described as "the proteiform graph" and "a polyhedron of scripture" ( $F W$ 107.08) thus pointing to a composite, multiform conception of writing comparable to Dante's own practice as he describes it in the "Epistle" (cf. §7, §9). The letter is also at one point identified with the "Tunc" page of the Book of Kells, and the style and language of its most famous interpreter, Sir Edward Sullivan, is parodied at some lenght ( $F W$ 119.10-123.10). This bears up the "medievalist" aspect of this chapter and of the "letter", and the need to appeal to (the interpretation of) medieval models for its interpretation; it also supports the point made earlier that the clearly separated layers of meaning we might expect to find are transformed into intricate threads that appear and disappear from view in a manner 
reminiscent of the technique of interlacing most evident in the Book of Kells's beautifully illuminated "letters". Dante's "Epistle" accompanied the third cantica of the Divine Comedy and dedicated it to Dante's patron at Verona; it also contained instructions as to how the poem should be read qualifying in a way as a "manifesto" of poetics; the "mamafesta", among many other things, contains similar notations of literary criticism, with instructions as to how the "letter" - with all that it stands for - should be deciphered.

After the statement of the polymorphous nature of the letter, a quest for its "true" author begins ("who in hallhagel wrote the durn thing anyhow?", $F W$ 107.36-108.01). While this may remind us that the true authorship of Dante's exegetical "Epistle" is not established with any certainty and that we still don't know who on earth, or indeed in hell, wrote the damn thing, the text suggests that in order to find an answer to this problem we must go back to the letter itself; but this philological search for textual clues is soon transformed into, or fused with, a search for an interpreter who could help us find out what it is all about, thus suggesting - as Dante himself claims ${ }^{15}$ - that the author is the best exegete of his own work, and taking us back, circularly, to the question of authorship ("Then as to this radiooscillating epiepistle to which ... we must ceaselessly return, whereabouts exactly ... is that bright soandsuch to slip us the dinkum oil?", $F W$ 108.24-28).

Unfortunately, the quest leads the researcher nowhere, if ten pages later "we must vaunt no idle dubiosity as to its genuine authorship and holusbolus authoritativeness" ( $F W$ 118.03-04). As for the "Epistle to Can Grande", over six hundred years have not been enough to dispel the dubiosity as to its genuine authorship, though critics do not vaunt any doubt as to its authoritativeness. All we know is that "somebody ... wrote it, wrote it all, wrote it all down, and there you are, full stop" ( $F W$ 118.12-14). In fact, by turning to the text, not only have we missed its author, but we may

15. Dante claims that one of the reasons why he wrote the Convivio is that he is moved by "desiderio di dottrina dare la quale altri veramente dare non può" ("the desire to give instruction which no one else can truly give", Conv I.ii, 15), because only he, as the author, can explain what his poems truly meant. 
have already lost sight of the text itself: depending on the interpretation we give to the prefix "epi-", the "epiepistle" may be a commentary upon the epistle itself (the letter which is found and described in the chapter, and, why not, perhaps even Dante's "Epistle", a commentary upon a text, an epi-text, as it were, which seeks to explain what "it" - the Paradiso - "is all about", or, in other words, "slip us the dinkum oil"); or it may also be the outer (or additional) layer over the epistle - the envelope? A "sovrasenso", as Dante defines the anagogical meaning? The attention is indeed devoted for a moment to the envelope: "Has any fellow ... ever looked sufficiently longly at a quite everydaylooking stamped addressed envelope?" (FW109.01-08). We are told that "admittedly it is an outer husk" (109.08) but that we should not "concentrate solely on the literal sense or even on the psychological content of any document to the sore neglect of the enveloping facts themselves circumstantiating it" ( $F W$ 109.12-14). The text goes on to develop its marked concern with appearance, face, clothing and what is underneath the surface:

Who in their heart doubts either that the facts of feminine clothiering are there all the time or that the feminine fiction, stranger than the facts, is there also at the same time, only a little to the rere? Or that one may be separated from the other? Or that both may then be contemplated simultaneously? Or that each may be taken up and considered in turn apart from the other? $(F W 109.30-36)^{16}$

In the Convivio, after the illustration of the four senses, Dante writes that

sempre lo litterale dee andare innanzi, sí come quello nella cui

16. The last two quotations are used by Samuel Beckett in his provocative argument against those who do not understand Joyce's Work in Progress, notably Rebecca West, whose "salivation" at "her intellectual banquets" (my emphasis) should require either that she "wear her bib," or "a more noteworthy control over her salivary glands" ("Dante... Bruno. Vico.. Joyce", p. 13). 
sentenza li altri sono inchiusi, e sanza lo quale sarebbe impossibile ed inrazionale intendere a li altri, e massimamente a lo allegorico. (Conv. II.i, 8)

("the literal sense must always come first, as the one in whose meaning the others are contained, and without which it would be impossible and irrational to attend to the others, and especially to the allegorical".)

The literal meaning comes first and encloses the others, so that they follow in the interpretation: "is there also at the same time, only a little to the rere" ( $F W 109.32-33)$. One should not concentrate only on the literal sense, neglecting the "enveloping facts": these are the circumstances of writing and of the transmission of the text, or maybe the envelope in which the letter is sealed. However, if we read the passage with Dante's words in mind, the "enveloping facts" should be the letter itself: "lo litterale ... ne la cui sentenza li altri sono inchiusi" ("the literal ... in whose meaning the others are included", Conv. II.i, 8). The stress on the envelope also makes the point that the form is just as important as its content - form and content are in fact one and the same thing, and they are reversible (Beckett writes, after quoting the same excerpts from the Wake I have reproduced above: "Here form is content, content is form" ${ }^{17}$ ). Similarly, the letter could not be delivered and reach its aim (the addressee and the goal of communication) without the envelope. In other words, the envelope also bears a message, the "instructions for use" directed to the postman and to the receiver, specifying where and to whom the letter should go, and where it comes from. In a way, Dante's letter to Can Grande, with its directions and "instructions for use", is to the text of the Paradiso what the envelope is to the letter.

The confusion is of course based on the ambiguity of the word "letter", which may be interpreted both as "epistle" and as "literal sense". The second passage ( $F W$ 109.30-36) also equivocates between Dante's terms. If the letter is the sense which enfolds the other three, one could say that it "clothes" them. Now, allegory, as

17. "Dante... Bruno. Vico.. Joyce”, p. 14. 
"alien" or "different" meaning, ${ }^{18}$ may be qualified as "stranger" ("stranger than the facts", where the facts would be the literal or historical sense). What in Finnegans Wake is defined as "stranger" is however the "fiction", which in the words of the Convivio is in fact again the literal sense, the "beautiful fiction" that veils allegory. This "fiction" is "only a little to the rere", this time like the allegorical meaning in Dante: "sempre lo litterale dee andare innanzi" ("the literal sense must always come first"). We could point out yet another paradoxical conclusion; if the allegory is "alien", i.e. strange(r), isn't H.C.E. - the barbarian, i.e. the stranger and the stutterer - the allegory par excellence? Neither of these two levels can ultimately be authoritative or grounded in any more stable truth than the other. By deliberately confusing the issue and by drawing attention to the envelope as well as to the letter proper, Joyce is moreover pointing out that layers of meaning go on proliferating in all directions and at all levels, crossing borders, becoming, as it were, "stranger(s)".

(There is another sense of "letter" that may be considered here, especially if one regards the meta-literary commentary of Finnegans Wake as a continuation of Stephen Dedalus' literary theorising in A Portrait and Ulysses: when the letter is French, and the meaning is a sexual one - a level not contemplated by Dante's fourfold specification - this level has to be the outer layer, or envelope; but in this case the "envelope" is not really conducive to a proliferation of (an)"other" (meaning). The difference between the sterility of the French and the proliferation of the Italian letter may ultimately discredit Stephen's accusations of spiritual-heroic frigidity levelled at the writer of the latter.... ${ }^{19}$ )

18. "Nam allegoria dicitur ab alleon graece, quod in latinum dicitur alienum, sive diversum" ("for the word 'allegory' is so called from the Greek alleon, which in Latin is alienum (strange) or diversum (different)", "Epistle to Can Grande", §7).

19. I discuss the complex interrelations between Stephen's literary theorizing, the Dantean intertext, and the use of letters, literary and geometrical figures in chapter 4 of my Joyce, Dante, and the Poetics of Literary Relations. 
In the Convivio, Dante still professes to be following the "modo de li poeti": for him, and for them, the letter is a charming lie and only the hidden allegorical meaning is true, form and content are separate. Joyce, for whom form and content coincide because they are one and the same thing, brings into the Wake an allusion to the text of Dante's Convivio by associating letter and other meanings with appearance and reality and the theme of clothes and feminine ornaments ${ }^{20}$ (see also "its face ... is its fortune", $F W$ 109.08-09), "fictional" insofar as they may be misleading; but in the same way as he blurs the distinction between Dante's levels, the demarcation between external appearance and hidden truth, on which any theory of allegory needs to rely, also loses any sharpness.

This metamorphosis of the model, however, only exposes and makes explicit what was already implicit and self-contradictory in Dante's theory. As I pointed out above, Aquinas writes that the figurative use of language must not be interpreted as the allegorical meaning of a text, as figures of speech belong to the letter; the literal sense, he further explains, is what the author wants to say (intentio auctoris); now, if the intention of the author is to communicate the significance which is hidden, the hidden sense must be considered the true literal sense. If we take this one step further, we can even say that the true literal sense turns out to be the allegorical one, because it represents the "true intention" of the author. ${ }^{21}$ If we

20. In a passage of the Convivio Dante states that the true value of a poem lies in its content and not in its form, often charming but misleading, and compares it with a woman whose beauty can be judged only when all exterior ornaments are laid aside: "Sì come non si può bene manifestare la bellezza d'una donna, quando li adornamenti de l'azzimare e de le vestimenta la fanno più ammirare che essa medesima. Onde chi vuole ben giudicare d'una donna, guardi quella quando solo sua naturale bellezza si sta con lei, da tutto accidentale adornamento discompagnata" ("Just as the beauty of a woman is not in good evidence when the adornment of her make up and clothes bring her more admiration than she brings herself. Thus whoever wants to judge a woman justly should look at her when only her natural beauty is with her, unaccompanied by any incidental adornment", Conv. I.x, 12-13)

21. Some of the implications of this perspective for Dante's theory are 
look at it in a Wakean perspective, we see that during the dream, the "intentio" of the unconscious is to release meanings once they have been censored and processed by the dream work, liberating them and letting them come to the surface through linguistic indices, still obscure, which however possess some qualities that can enable the analyst - or the literary critic, or the exegete, as the case may be - to discover the truth beneath them, the "true intention" of the author / mind. Whether it is by a conscious contamination of Dante with St. Thomas or not, it looks as though Joyce's text, starting from Dante, goes beyond him to fall back again on yet another appropriation, for its own ends and on its own terms, of the mentor of Stephen Dedalus's youthful aesthetic elaborations. (Yet one wonders what the Angelic Doctor would have made of the difference between French and Florentine letters...)

There is at least an analogy between Dante and Joyce's use of polysemy that ought however to be pointed out. For both writers the polysemic method becomes one of construction (as in the "method of the poets") as well as one of interpretation (the "method of the theologians"). The allegory (in its comprehensive meaning of "sense other") can be synthesised in the formula "this and that", and no longer "this for that", as was the case with the allegory of the poets in the Convivio. Joseph Mazzeo makes an interesting point about Dante's definition of allegory in the "Epistle", where it can also be taken as a general term subsuming the three senses allegorical proper, moral and anagogical:

One of Dante's intentions, in discussing allegory, is not so much to advance a theory of explication as to describe a theory of the selection and ordering of significant experience. It is thus that the meaningful intellectual and personal experience of a lifetime is compressed into the "time" of one week. ${ }^{22}$

Dante's theory of the four levels of meaning is a means of

discussed in Jean Pépin, Dante et la tradition de l'allegorie, Paris: Vrin, 1970. Cf. esp. pp. 74-79.

22. Joseph A. Mazzeo, Structure and Thought in the Paradiso, Ithaca, New York: Cornell UP, 1958, p. 34. 
selection and ordering of experience: not so in the Wake, where it is, rather, a means of inclusion, and probably of disordering, of all experience. Whereas in Dante the alleon is conveyed (hidden) by the letter, in Finnegans Wake it is simultaneously present together with the letter, and, as we have seen, it may be the letter itself which is in fact hidden. As the alienum is everything that is "other" from what is printed on the page, and the printed word has both a literal and an allegorical meaning, taking this to extreme consequences, the words of the book mean both what is there and what is not - that is to say, potentially everything; one of Joyce's favourite and best-known word-plays is the pun on word / world: the word on the page is a microcosm containing in itself the entire macrocosm. The road from Dante's selective polysemy to the Wake's allinclusiveness passes through Giordano Bruno's theory of the coincidence of the opposites in the one and his conception of the infinity of the universe and its simultaneous presence in all things. As Tambling argues in an essay earlier in this volume, Bruno's theory in turn links back to the heretical theory of the medieval Arab philosopher Averroes, whose dualism ultimately points to an irreducible plurality.

Reed Dasenbrock and Ray Mines rightly argue in their essay in this collection that Joyce imitates Dante better than Pound does because he follows the medieval writer's poetics rather than slavishly trying to reproduce the features of the original, and Dante's poetics implied using everything that is up-to-date. It is of course also equally true that Dante himself figures highly among the up-to-date knowledge and interests of Joyce's time, and that therefore the issue of imitation will also have to confront (in a modern manner) the contents of Dante's texts too - as textbooks, in a sense, from which one learns how to write. Part of the lesson is to learn how to steal from one's masters: it is this very modernist concept of stealing in order to be original that Dante proposes in canto XXV of the Inferno, where the pilgrim-poet finally abandons the mask of the unworthy follower and of deference towards the auctoritates of the literary and spiritual past ("io non Enea, io non Paulo sono", ${ }^{23}$ Inf. II, 32). Joyce challenges the Florentine poet on

23. "I am not Aeneas, I am not Paul". 
his own medieval interpretative and literary ground and (implicitly) claims to surpass him in the same way as Dante himself had (explicitly) claimed in the Divine Comedy to surpass his poetic predecessors and models when he described the metamorphoses of the thieves. Just as for Dante the wondrous transformations of Inferno XXV allegorize the dynamics of literary relations, so for Joyce the dissolution of the medieval allegorical theory into a more fluid and unredeemable polysemy in his own Letter becomes itself an allegorization of the modernist relation to literary tradition.

\section{London}

